3 Dyck, W P, et al, Gastroenterology, 1978, 74, 410.

4 Englert, E, et al, Gastroenterology, 1978, 74, 416.

${ }^{5}$ Hentschel, E, Schütze, K, and Havelec, L, Wiener Klinische Wochenschrift, 1979, 91, 53.

6 Peter, P, et al, Deutsche medizinische Wochenschrift, 1978, 103, 1163.

7 Scheurer, U, et al, Gastroenterology, 1977, 72, 838.

${ }^{8}$ Classen, M, and Ruppin, H, Endoscopy, 1974, 6, 127.

${ }^{9}$ Lindner, H, and Fintelmann, V, Leber Magen Darm, 1971, 1, 155.
${ }^{10}$ Lindner, H, Zeitschrift für Gastroenterologie, 1972, 10, 387.

${ }^{11}$ Heinkel, K, and Kimmig, J M, Zeitschrift für Gastroenterologie, 1971, 9, 331

${ }^{12}$ Heinkel, K, and Kimmig, J M, Zeitschrift für Gastroenterologie, 1972, 10, 393.

13 Paoluzi P, Italian fournal of Gastroenterology. In press.

(Accepted 13 September 1979)

\title{
Incidence of malignant melanoma of the skin in England and Wales and its relationship to sunshine
}

\section{A J SWERDLOW}

British Medical fournal, 1979, 2, 1324-1327

\section{Summary and conclusions}

In most of England and Wales the incidence of malignant melanoma of the skin has risen rapidly in recent years, especially in women. Mean incidences in the 14 English health regions and Wales correlated negatively with latitude and positively with hours of sunshine, suggesting that exposure to sunshine was an important causal factor. Male and female incidences within a region tended to show similar yearly fluctuations, implying a common factor affecting the incidence in both men and women with a short latent period of action.

This factor may be exposure to sunshine, which may cause melanoma after an induction period of about two years; for women the incidence of melanoma in the regions of England and Wales correlated positively with hours of sunshine two years earlier.

\section{Introduction}

In white populations in recent years melanoma has accounted for most of the deaths from skin cancer, and the incidence of melanoma and its mortality have been rising faster than rates for any other cancer except, in some countries, lung cancer.

Epidemiological evidence indicates that exposure to sunlight may be an important causal factor in skin melanoma, ${ }^{12}$ although this is disputed. ${ }^{2}$ The evidence is less complete than that for the relationship between sun exposure and squamous-cell skin carcinomas. ${ }^{3}$ Recent reports ${ }^{4}{ }^{5}$ show an increased incidence of melanoma about two years after periods of increased sunspot activity. The rising trend in incidence may also be due to some extent to sunlight exposure. Concern has been expressed that the increasing use of fluorocarbon aerosol propellants and refrigerants and supersonic air travel may increase the shortwavelength ultraviolet (UV) radiation reaching the earth's surface and thus lead to an increase in the incidence of skin cancer. ${ }^{6}$

This paper explores the rising incidence of malignant melanoma of the skin and the nature of the relationship between sun exposure and the occurrence of melanoma, based on 24 years' data for the Oxford Region and rather fewer years for the rest of England and Wales.

Oxford Regional Health Authority, Headington, Oxford A J SWERDLOW, MA, BM, senior registrar in community medicine
Method

INCIDENCE OF MALIGNANT MELANOMA OF THE SKIN

For Oxford Region* residents directly age-standardised sex-specific annual incidence rates for 1952-75 were calculated using the 1961 Oxford Region population as the standard. Incidence data were obtained from the Oxford Cancer Registry and age-specific population data for 1955-74 from published sources. ${ }^{7}$ The age distribution of the population were estimated for 1952-54 and 1975, for which the data were not yet published.

The long series of incidence data obtained for Oxford Region were not available for other regions of England and Wales; the longest series available were crude incidence rates for 1955-69 in the Southwestern Region ${ }^{8}$ and crude rates for $1962-70$ in the other regions and in England and Wales overall. ${ }^{9}$

For each set of data the mean incidence, the rate of increase in incidence (slope of the linear regression line of incidence on year) and the incidence expected in each year on the basis of linear regression of incidence on year were calculated.

\section{SUNSHINE}

For each region the measurements of mean daily hours of bright sunshine used were those recorded at the meteorological office "District values station"10 nearest to the main population centre(s) of each region. In the South-western Region no one station was representative and therefore the mean of data for two stations was adopted. For Wales a station in mid-Wales had to be used since complete data for 1960-8 were not available for any station in south Wales (where most of the population live). For England and Wales overall hours of sunshine were obtained from the Registrar General's Statistical Review of England and Wales. ${ }^{11}$

\section{CORRELATIONS}

For each region, for men and for women separately, the mean incidence and the rate of increase in incidence were correlated with the latitude representative of the main population centre(s) of the region and with hours of sunshine in the region two years earlier (the most likely induction period ${ }^{45}$ ). To examine the extent to which male and female rates fluctuated together from year to year when longer-term trends were discounted, the correlation was calculated for each region between the deviations of male incidence rates in each year from male linear regression expectation and the deviations of the female rates for the same years from female linear regression expectations.

To test whether, when longer-term trends were discounted, hours of sunshine affected the incidence of melanoma two years later the correlation was calculated between the annual deviations from linear regression expectation of melanoma incidence and the deviations from linear regression expectation of annual hours of sunshine two

*Throughout, the Oxford Region refers to the area covered by the Oxford Regional Hospital Board in 1952-73 and that covered by the Oxford Regional Health Authority in 1974 and 1975. The difference between these areas is small and unlikely to have affected the results substantially. 
years earlier. For comparison, the correlations were then repeated using series of sunshine data (deviations from regression expectation) one year, three years, four years, and five years before the incidence data.

\section{Results and comment}

From 1952 to 1975 the age-standardised incidence rate for malignant melanoma of the skin in the Oxford Region approximately tripled in both sexes (fig 1). In the South-western Region in 1955-69 the incidence rate more than doubled in women and also increased in men. In England and Wales both male and female rates increased

TABLE I-Mean incidence and rate of increase in incidence of melanoma in men and women 1962-70 and hours of sunshine 1960-8 in the regions of England and Wales

\begin{tabular}{|c|c|c|c|c|c|}
\hline \multirow{2}{*}{$\begin{array}{l}\text { Hospital } \\
\text { region of } \\
\text { residence }\end{array}$} & \multicolumn{2}{|c|}{$\begin{array}{c}\text { New cases per } 100000 \\
\text { population per annum* } \\
\text { (and mean number of cases) }\end{array}$} & \multicolumn{2}{|c|}{$\begin{array}{c}\text { Rise in incidence per } \\
100000 \text { population per } \\
\text { annum* (regression } \\
\text { coefficient) }\end{array}$} & \multirow{2}{*}{$\begin{array}{c}\text { Mean } \\
\text { daily } \\
\text { hours of } \\
\text { bright } \\
\text { sunshine } \\
1960-8\end{array}$} \\
\hline & Men & Women & Men & Women & \\
\hline England and Wales & $1 \cdot 38(323)$ & $2.59(639)$ & 0.04 & 0.08 & 3.86 \\
\hline South-western & & $\mathbf{4} \cdot \mathbf{7 7}$ & $0 \cdot c$ & & \\
\hline Wesse: & $1.37(13)$ & $2.65(26)$ & $0 \cdot 10$ & 0.08 & \\
\hline SW Metropolitan & $1.91(29)$ & $3.31(56)$ & 0.17 & $0 \cdot 14$ & 3.92 \\
\hline SE Metro & $1.76(29)$ & $3.26(59)$ & 0.03 & 0.11 & $4 \cdot 14$ \\
\hline NE Metropolitan & $1.32(21)$ & $2 \cdot 12(37)$ & -0.01 & -0.05 & 4.34 \\
\hline NW Metropolitan & $1.59(32)$ & $2.75(60)$ & 0.04 & 0.13 & 3.75 \\
\hline Oxford & $1.62(15)$ & $3 \cdot 15(29)$ & $0 \cdot 18$ & 0.15 & $4 \cdot 03$ \\
\hline Wales & 1.35 (18) & $2 \cdot 12(29)$ & 0.04 & $-0 \cdot 10$ & $3 \cdot 17$ \\
\hline East Anglia.. & 1.66 (14) & $3 \cdot 12(26)$ & 0.01 & 0.12 & 3.79 \\
\hline Birmingham & $1.41(35)$ & $2.51(63)$ & 0.07 & 0.08 & 3.47 \\
\hline Sheffield . & $1.26(29)$ & $1.96(45)$ & -0.02 & 0.03 & $3 \cdot 25$ \\
\hline Liverpool & $0.93(10)$ & $2 \cdot 19(26)$ & -0.02 & -0.0 & 4.05 \\
\hline Manchester.. & $0.97(21)$ & $1.89(44)$ & 0.04 & 0.04 & 3.59 \\
\hline Leeds $\quad$. & 0.75 (12) & $1.71(28)$ & 0 & 0. & \\
\hline Newcastle .. & $1.07(16)$ & $2 \cdot 32(36)$ & -0 & $0 \cdot 13$ & 3.45 \\
\hline
\end{tabular}

${ }^{*}$ Crude rates throughout. ${ }^{9}$ †Exact locations specified in table III.

TABLE II-Correlations between incidence of melanoma and rate of increase in incidence in the 15 regions of England and Wales and latitude of regions and hours of sunshine in regions

\begin{tabular}{|c|c|c|c|c|}
\hline & \multicolumn{2}{|c|}{$\begin{array}{c}\text { Mean incidence } \\
1962-70\end{array}$} & \multicolumn{2}{|c|}{$\begin{array}{l}\text { Rate of increase of } \\
\text { incidence } \\
1962-70\end{array}$} \\
\hline & Men & Women & Men & Women \\
\hline $\begin{array}{l}\text { Latitude } \\
\text { Mean daily hours of }{ }^{\circ} \text { bright } \\
\text { sunshine } 1960-8\end{array}$ & $\begin{array}{c}-0.80^{* * *} \\
0.50\end{array}$ & $\begin{array}{r}-0.63^{*} \\
0.57^{*}\end{array}$ & $\begin{array}{c}-0.57^{*} \\
0.27\end{array}$ & $\begin{array}{r}-0.19 \\
0.29\end{array}$ \\
\hline
\end{tabular}

***P<0.001. * $\mathrm{P}<0.05$

All incidence data from Registrar General." significantly from 1962 to $1970(\mathrm{P}<0.01)$; the incidences rose for women in all but three regions and for men in all but four regions, the increases generally being greater in women (table I). In every region the mean incidence in 1962-70 was higher in women than in men (table I), the female to male ratio ranging from 1.55 in the Sheffield Region to 2.39 in the South-western Region. Both the mean incidence of melanoma and the rate of secular increase of incidence were negatively correlated with latitude and positively correlated with hours of sunshine, several of these correlations being significant (table II, fig 2).

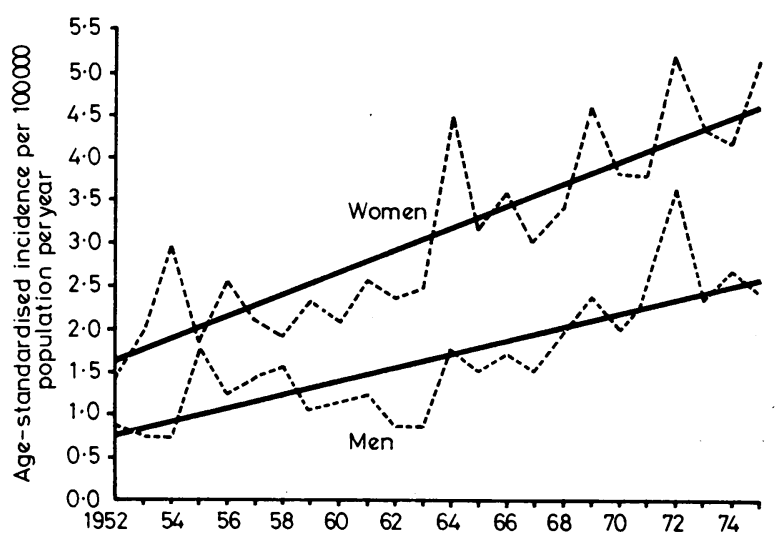

FIG 1-Age-standardised incidence of malignant melanoma of the skin in Oxford Region 1952-75. Annual incidence rate (broken lines) is shown with regression of incidence on year (solid lines).

The incidence of melanoma in women for individual years correlated positively with the incidence in men for the corresponding years (after discounting long-term trends) in all but three of the 15 regions $(P<0.05$ in three regions and $\mathbf{P}<0.01$ for all region-years combined) and for England and Wales (table III). Plotting the data for each region on a graph gave no evidence that the correlations were an artefact of systematically non-linear data or of a few extreme data points.

For women the correlations between the incidence of melanoma and hours of sunshine two years earlier, after discounting long-term trends, suggested an association (table III); the correlation was positive in 11 of the 15 regions $(P<0.01$ in one region); the correlations in the larger data sets were more strongly positive than in most of the smaller sets, with a significant $(P<0.05)$ correlation for all regionyears combined and borderline significant correlations for England and Wales and for the only long set of age-adjusted data (Oxford 1952-75)

No other time interval showed a strong pattern of positive correla-

TABLE III-Correlation between incidences of melanoma in men and women and between incidence and hours of sunshine two years earlier after linear trends removed by regression

\begin{tabular}{|c|c|c|c|c|c|c|c|c|c|c|c|}
\hline \multirow{2}{*}{\multicolumn{6}{|c|}{ Hospital region of residence }} & \multirow{2}{*}{$\begin{array}{l}\text { Period of incidence } \\
\text { data }\end{array}$} & \multirow{2}{*}{$\begin{array}{l}\text { Location at which } \\
\text { sunshine measured }\end{array}$} & \multirow{2}{*}{$\begin{array}{l}\text { Period of } \\
\text { sunshine data }\end{array}$} & \multirow{2}{*}{$\begin{array}{l}\text { Correlation of } \\
\text { male with female } \\
\text { incidence }\end{array}$} & \multicolumn{2}{|c|}{$\begin{array}{l}\text { Correlation of incidence } \\
\text { with hours of sunshine }\end{array}$} \\
\hline & & & & & & & & & & Men & Women \\
\hline \multirow{2}{*}{\multicolumn{2}{|c|}{$\begin{array}{l}\text { England and Wales } \\
\text { South-western }\end{array}$}} & . & .. & . & .. & $1962-70$ & \multirow{16}{*}{$\begin{array}{l}\text { England and Wales } \\
\text { Long Ashton } \\
\text { Plymouth Hoe } \\
\text { Southampton } \\
\text { Wisley } \\
\text { East Mean } \\
\text { Shoeburyng } \\
\text { Rothamsted } \\
\text { Oxford } \\
\text { Llandrindod Wells } \\
\text { Sprowston } \\
\text { Birmingham } \\
\text { Nottingham } \\
\text { Bidston } \\
\text { Ringway } \\
\text { Huddersfield } \\
\text { Durham } \\
\end{array}$} & $1960-68$ & 0.43 & 0.46 & 0.63 \\
\hline & & . & $\cdots$ & * & . & $1955-69$ & & $1953-67$ & -0.07 & -0.04 & $0 \cdot 16$ \\
\hline \multirow{5}{*}{\multicolumn{2}{|c|}{$\begin{array}{l}\text { Wessex } \\
\text { SW Metropolitan } \\
\text { SE Metropolitan } \\
\text { NE Metropolitan } \\
\text { NW Metropolitan }\end{array}$}} & .. & .. & .. & .. & $1962-70$ & & $1960-8$ & $0.79 *$ & -020 & 0.01 \\
\hline & & . & .. & . & .. & " & & $"$ & $\begin{array}{r}0 \cdot 29 \\
0.48\end{array}$ & 0.07 & $0.81^{* *}$ \\
\hline & & .. & .. & . & .. & " & & ” & 0.48 & 0.25 & 0.06 \\
\hline & & .. & .. & .. & .. & $"$ & & ” & $0 \cdot 38$ & -0.48 & $-0 \cdot 10$ \\
\hline & & 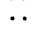 & $\ldots$ & . & . & - & & -" & $0 \cdot 20$ & 0.46 & 0.20 \\
\hline Oxford & .. & . & .. & .. & . & $1952-75$ & & $1950-73$ & 0.40 & 0.21 & 0.37 \\
\hline Wales ... & .. & . & $\cdots$ & $\cdots$ & . & $1962-70$ & & $1960-8$ & 0.58 & -0.29 & -0.29 \\
\hline East Anglia & .. & .. & .. & $\cdots$ & $\cdots$ & ") & & " & 0.08 & $0 \cdot 60$ & $0 \cdot 20$ \\
\hline Birmingham & .. & .. & .. & .. & .. & " & & " & 0.49 & -0.22 & -0.50 \\
\hline Sheffield & . & .. & .. & .. & .. & ” & & " & 0.06 & -0.21 & $0 \cdot 18$ \\
\hline Liverpool & $\therefore$ & $\ldots$ & .. & .. & .. & 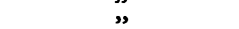 & & $"$ & $-0 \cdot 15$ & -0.20 & 0.55 \\
\hline Manchester & .. & .. & .. & . & .. & $"$ & & " & $0.71^{*}$ & 0.24 & 0.59 \\
\hline Leeds .. & .. & .. & .. & .. & .. & " & & 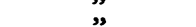 & $0.75^{*}$ & -0.41 & -0.58 \\
\hline Newcastle & .. & .. & .. & .. & . & " & & ” & -0.41 & -0.01 & 0.07 \\
\hline All regions & .. & .. & .. & . & . & $\begin{array}{l}\text { Longest incidence } \\
\text { period available for } \\
\text { each region }\end{array}$ & $\begin{array}{l}\text { District values station for } \\
\text { each region, as above }\end{array}$ & $\begin{array}{l}\text { Sunshine periods } \\
\text { two years } \\
\text { before } \\
\text { incidence }\end{array}$ & $0 \cdot 25^{* *}$ & 0.07 & $0 \cdot 17^{*}$ \\
\hline
\end{tabular}


TABLE IV-Correlations between incidence of melanoma in women and men and hours of sunshine at various lag periods before incidence, after linear trends removed by regression

\begin{tabular}{|c|c|c|c|c|c|c|c|c|c|c|c|c|c|}
\hline \multirow{2}{*}{\multicolumn{3}{|c|}{ Lag period: }} & & \multicolumn{5}{|c|}{ Women } & \multicolumn{5}{|c|}{ Men } \\
\hline & & & & 1 Year & 2 Years & 3 Years & 4 Years & 5 Years & 1 Year & 2 Years & 3 Years & 4 Years & 5 Years \\
\hline \multicolumn{2}{|c|}{$\begin{array}{l}\text { England and Wales } \\
\text { South-western .. } \\
\text { Wessex . . . } \\
\text { SW Metropolitan } \\
\text { SE Metropolitan .. } \\
\text { NE Metropolitan.. } \\
\text { NW Metropolitan } \\
\text { Oxford .. }\end{array}$} & $\begin{array}{l}. \\
\because \\
\because \\
\because \\
\because \\
\because \\
\because \\
\because \\
\because \\
\because \\
\therefore \\
.\end{array}$ & $\begin{array}{l}\ldots \\
\ldots \\
\cdots \\
\cdots \\
\cdots \\
\cdots \\
\because \\
\cdots \\
\cdots \\
\cdots\end{array}$ & $\begin{array}{c}-0.74^{*} \\
-0.40 \\
0.63 \\
-0.59 \\
-0.02 \\
-0.49 \\
-0.36 \\
-0.24 \\
-0.61 \\
-0.74^{*} \\
0.19 \\
-0.46 \\
-0.35 \\
-0.24 \\
0.56 \\
-0.38\end{array}$ & $\begin{array}{l}0.63 \\
0.16 \\
0.01 \\
0.81 * * \\
0.06 \\
-0.10 \\
0.20 \\
0.37 \\
-0.29 \\
0.20 \\
-0.50 \\
0.18 \\
0.55 \\
0.59 \\
-0.58 \\
0.07\end{array}$ & $\begin{array}{c}0.15 \\
-0.45 \\
0.38 \\
-0.71^{*} \\
-0.22 \\
-0.37 \\
-0.42 \\
-0.08 \\
-0.08 \\
0.27 \\
0.30 \\
0.11 \\
-0.42 \\
0.39 \\
0.54 \\
-0.14\end{array}$ & $\begin{array}{c}-0.24 \\
0.73 * * \\
-0.04 \\
0.06 \\
-0.30 \\
-0.32 \\
0.16 \\
-0.18 \\
-0.18 \\
0.07 \\
-0.06 \\
0.29 \\
0.31 \\
-0.33 \\
-0.18 \\
-0.21\end{array}$ & $\begin{array}{l}0.34 \\
-0.23 \\
-0.39 \\
-0.08 \\
0.30 \\
0.69^{*} \\
0.62 \\
0.60^{* *} \\
0.20 \\
-0.30 \\
-0.44 \\
-0.20 \\
0.16 \\
0.51 \\
-0.39 \\
-0.32\end{array}$ & $\begin{array}{c}-0.43 \\
0.01 \\
0.23 \\
0.48 \\
0.21 \\
0.45 \\
-0.94^{* * *} \\
-0.06 \\
-0.55 \\
-0.78^{*} \\
0.13 \\
0.47 \\
-0.32 \\
-0.28 \\
0.37 \\
-0.24\end{array}$ & $\begin{array}{r}0.46 \\
-0.34 \\
-0.20 \\
0.07 \\
0.25 \\
-0.48 \\
0.46 \\
0.21 \\
-0.29 \\
0.60 \\
-0.22 \\
-0.21 \\
-0.20 \\
0.24 \\
-0.41 \\
-0.01\end{array}$ & $\begin{array}{r}0.17 \\
0.21 \\
0.19 \\
-0.62 \\
0.01 \\
-0.33 \\
-0.15 \\
0.10 \\
0.02 \\
-0.36 \\
0.03 \\
0.60 \\
0.28 \\
0.29 \\
0.55 \\
0.13\end{array}$ & $\begin{array}{r}-0.11 \\
-0.14 \\
-0.08 \\
0.61 \\
-0.08 \\
-0.10 \\
-0.28 \\
-0.23 \\
-0.06 \\
0.00 \\
0.23 \\
-0.65 \\
-0.25 \\
0.25 \\
-0.39 \\
-0.18\end{array}$ & $\begin{array}{c}-0.17 \\
0.14 \\
-0.14 \\
-0.79 * \\
-0.24 \\
-0.02 \\
0.63 \\
0.21 \\
0.67 * \\
0.14 \\
-0.70^{*} \\
0.33 \\
0.60 \\
0.52 \\
-0.02 \\
0.53\end{array}$ \\
\hline \multicolumn{3}{|c|}{ All regions combined } & $\ldots$ & $-0 \cdot 26 * *$ & $0 \cdot 17^{*}$ & -0.07 & 0.04 & 0.08 & -0.08 & 0.07 & 0.05 & $-0 \cdot 12$ & $0 \cdot 13$ \\
\hline
\end{tabular}

${ }^{*} \mathrm{P}<0.05 . \quad{ }^{* *} \mathrm{P}<0.01 . \quad{ }^{* * *} \mathrm{P}<0.001$.

One year lag correlations for East Anglia and Leeds Regions were based on incidence of melanoma in 1962-9 and sunshine in 1961-8, since 1969 sunshine data were not available. All other data on melanoma and sunshine locations were as in table III.

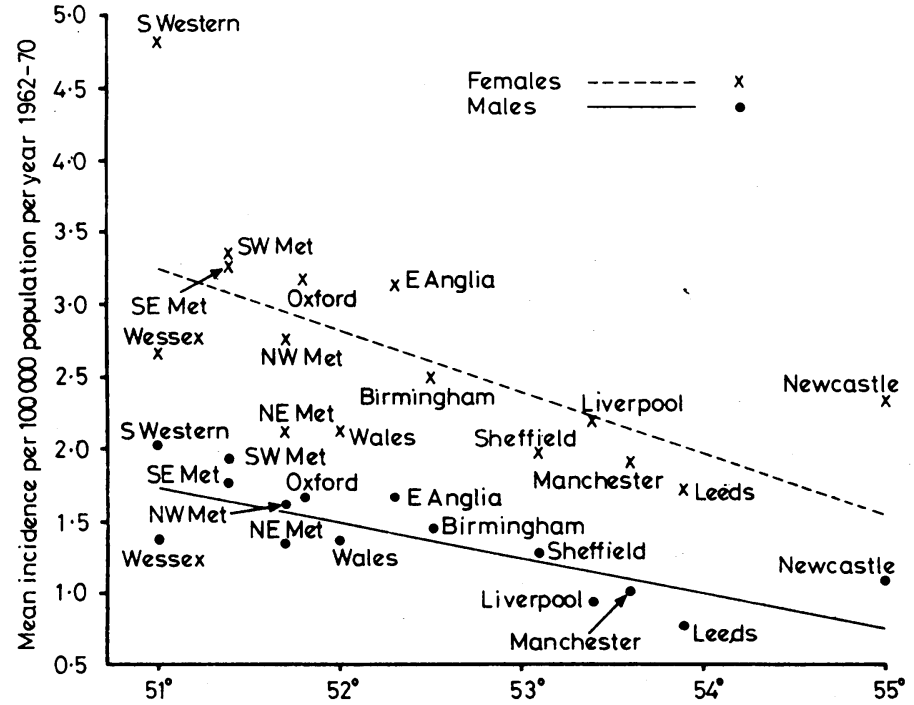

FIG 2-Correlation between incidence of malignant melanoma of the skin and latitude in the 15 regions of England and Wales 1962-70.

tions for women (table IV); occasional correlations for individual regions reached statistical significance, but some significant correlations would be expected by chance with the large number of correlation calculated. After a one-year period, a strong pattern of negative correlations was present: there were negative correlation coefficients for all but three regions, for England and Wales $(P<0.05)$, and for all region-years combined $(P<0.01)$. This finding for the one-year interval is difficult to interpret; it is unlikely to have any direct causal significance-that is, reflect a protective effect of sunshine-and it does not seem to be incompatible with the suggestion of a two-year induction period.

For men, no association between the yearly incidence of melanoma and prior sunshine was apparent for any lag interval. The two-year period gave negative correlations for nine regions and positive correlations for six regions, for England and Wales, and for all region-years combined; none of the correlations were significant. No pronounced pattern of correlations was found for any of the other periods examined.

\section{Discussion}

\section{RISE IN INCIDENCE}

The sharp rise in the incidence rate of malignant melanoma in Oxford and much of the rest of England and Wales in recent years accords with the rapid increase in incidence noted in white races in various other parts of the world. ${ }^{2312-14}$ As in several other countries, ${ }^{213}$ the rise in England and Wales probably mainly represents a genuine increase in incidence rather than better recognition or altered definitions of the disease or better registration (although improved registration appears to account for a minor part of the rise). The cause of the increase is not known; changes in hours of sunshine over the period have been minor compared with the rise in incidence, but sun exposure could be a causal factor via increased shortwave UV radiation reaching the earth's surface, increased duration of sunbathing, thinner garments, or less skin covered by garments.

\section{SEX DIFFERENCES}

The greater incidence rate in women than in men found in all regions of England and Wales is seen in several other countries in high latitudes, such as Canada and Denmark, ${ }^{15}$ but over most of the world there is no consistent pattern. The higher incidence in women and their generally stronger correlations between incidence and sunshine might reflect greater average exposure of skin to sunlight (or sunburn) by women in England and Wales (both by sunbathing and by the style of clothing worn in everyday life).

\section{INFLUENCE OF HOURS OF SUNSHINE AND LATITUDE}

The increase in the incidence of melanoma with decreasing latitude found within England and Wales has previously been shown within Australia, USA, Norway, ${ }^{2}$ and Finland. ${ }^{14}$ An increase in mortality with decreasing latitude has also been shown within Australia, ${ }^{16}$ New Zealand, ${ }^{16}$ the United States, ${ }^{10}$ and Canada $^{1}$ as well as a general mortality gradient with latitude between countries with predominantly "European" populations. ${ }^{16}$ The increase in the incidence of melanoma with decreasing latitude in several countries seems likely to be due to greater exposure to sunshine (intensity or duration, or both) closer to the equator; the positive correlation (table II) between hours of sunshine and incidence of melanoma in this study accords with this explanation. Nevertheless, alternative explanations may apply for some countries-for example, in Finland ${ }^{14}$ a coincident urban-rural gradient was found to explain the gradient of incidence with latitude.

The associations of rate of secular increase in the incidence of melanoma with latitude (negative correlations) and with hours of sunshine (positive correlations) could reflect a causal role for sunshine in the increase in incidence of melanoma in England and Wales. However, the associations partly reflect greater absolute 
increases where the initial rates were higher, and therefore a cause other than sunshine with a multiplicative effect on the incidence of melanoma could also be an explanation.

\section{INDUCTION PERIOD}

The strong association found between the annual fluctuations of female incidence rates and the annual fluctuations of male incidence is particularly striking in view of the small number of cases per year and of years of data available in most regions. Unless it was an artefact of the registration process, which seems unlikely since the correlation was found in so many regions, it strongly suggests that a factor common to men and women affects the incidence of melanoma with a short latent period of action; a latent period of many years would probably have too much dispersion around the mean to show such a pattern. The short latency is best explained by a short induction period between carcinogenic exposure and cancer incidence.

The correlations found in this study suggest an association between the incidence of melanoma in women and hours of sunshine two years earlier. If not due to chance, this association seems likely to be due to a causal relationship between sun radiation (or a factor closely associated with it) and the incidence of melanoma two years later. Hours of sunshine show no regular pattern and therefore it would be difficult to explain the association by causes unrelated to sunshine.

Further evidence for an induction period of about two years between exposure to sun radiation and the appearance of melanoma comes from previous work. Houghton et al ${ }^{4}$ presented correlations suggesting induction periods related to sunspots of two years for men and both sexes combined in Connecticut and for men in New York State; one to two years for both sexes combined in New York State, and up to one year in Finland. They did not present separate correlations for women. Wigles presented data for Alberta and Saskatchewan suggesting an induction period related to sunspots of up to two years. Because sunspot activity is cyclic, a 10 -year induction period is also a possible explanation of these findings ${ }^{5}$ (this alternative does not apply to correlations with hours of sunshine because hours of sunshine are not cyclic). Although these studies related the incidence of melanoma to the incidence of sunspots rather than to hours of sunshine, both may represent the same underlying cause. Each may be a cause of substantial annual variation in sun radiation exposure in some countries, with the relative contributions of each varying between countries.

Two years from carcinogenic exposure to the appearance of cancer is very short compared with most known induction periods for human cancers, but there are other human cancers for which there is evidence of a short induction period. Endometrial cancer after exposure to exogenous oestrogens is thought to have an induction period from first exposure of about four to eight years ${ }^{17}$ or, possibly, recent work suggests, much less. ${ }^{1 *}$ The risk of lymphoma after renal transplantation rises to a maximum within a few months of transplantation and remains at that level for several years. ${ }^{19}$ After irradiation in utero there is an increased relative risk of cancer even in the first two years of life, a risk maximal in children dying at the ages of 6-7 years, ${ }^{20}$ and induction periods of less than three years have been noted for neuroblastoma, retinoblastoma, and Wilms's tumours. ${ }^{21}$

The conclusions drawn from the population-based correlations presented above must necessarily be circumstantial, ${ }^{22}$ and the hypothesis of a two-year induction period needs further testing. In particular, it would be of interest to repeat the analysis on data from other countries where there is considerable annual variation in sunshine and to test by case-control studies whether a holiday in a hot sunny country is a risk factor for the appearance of melanoma two years later in a resident of Britain or another country with a similar climate. The incidence pattern of melanoma in Britain after the extremes of weather in the past few years will also be of great interest.
I thank Professor M P Vessey, Mr P G Smith, Dr A Barr, Dr M J Goldacre, Dr R H Cowdell, and Mr D Golding for advice; Miss C Hunt and her staff at Oxford Cancer Registry for information on Oxford cases; and Mrs M Biggs and her staff for typing.

\section{References}

${ }^{1}$ Elwood, J M, et al, International fournal of Epidemiology, 1974, 3, 325.

2 Magnus, K, Cancer, 1973, 32, 1275.

${ }^{3}$ Lancet, 1978, 2, 822.

${ }^{4}$ Houghton, A, Munster, E W, and Viola, M V, Lancet, 1978, 1, 759.

5 Wigle, D T, Lancet, 1978, 2, 38.

${ }^{6}$ Lancet, 1978, 1, 537.

'Department of Health and Social Security and Office of Population Censuses and Surveys. Report on Hospital In-patient Enquiry. Tables. For the years 1955-74. London, HMSO, 1959-78.

${ }^{*}$ Walker, R M, Cancer in South West England. A Review of Incidence and Survival for the Years 1955-1969. Supplementary Report. Bristol, South-western Regional Cancer Bureau, 1972.

${ }^{9}$ Office of Population Censuses and Surveys, Registrar General's Statistical Review of England and Wales. Supplement on Cancer. For the Years 1962-1964, 1965, 1966-1967, 1968-1970. London, HMSO, 1968, 1970, $1972,1975$.

${ }^{10}$ Meteorological Office, Monthly Weather Report. Summary. For the Years 1947-1974, 64-91. London, HMSO, 1948-1976.

${ }^{11}$ Office of Population Censuses and Surveys. Registrar General's Statistical Review of England and Wales. Part I. Tables, Medical. For the Year 1970. London, HMSO, 1972.

12. McGovern, V J, Pathology, 1977, 9, 233.

${ }_{13}$ Lee, J A H, Progress in Clinical Cancer, 1975, 6, 151.

14 Teppo, L, Pakkanen, M, and Hakulinen, T, Cancer, 1978, 41, 2018.

${ }^{15}$ Waterhouse, J, et al (editors), Cancer Incidence in Five Continents, vol III. Lyon, International Agency for Research on Cancer, 1976.

${ }_{16}$ Lancaster, H O, Medical fournal of Australia, 1956, 1, 1082.

17 Marrett, L D, et al, Gynecologic Oncology, 1978, 6, 183.

$18 \mathrm{Jick}, \mathrm{H}$, et al, New England Fournal of Medicine, 1979, 300, 218.

19 Hoover, R, and Fraumeni, J F, jun, Lancet, 1973, 2, 55.

${ }^{20}$ Advisory Committee on the Biological Effects of Ionizing Radiations, Effects on Populations of Exposure to Low Levels of Ionizing Radiation. Washington, DC, Division of Medical Sciences, National Academy of Sciences, National Research Council, 1972.

${ }^{21}$ Stewart, A, and Barber, R, British Medical Bulletin, 1971, 27, 64.

${ }^{22}$ Fraser, P, Beral, V, and Chilvers, C, Fournal of Epidemiology and Community Health, 1978, 32, 294.

(Accepted 4 September 1979)

ONE HUNDRED YEARS AGO A correspondent, writing from Safed Sung, near Gundamuck, says: In the conflict on April 2nd, at Futteabad, near Jellalabad, between some of our forces of the 1st Division, under command of General Gough, and a large and determined body of Afghans, a large number of the latter were killed and wounded. Since the arrival of Sir Samuel Browne and Major Cavagnari at Safed Sung, it has been ascertained that the greater number of the men against whom we then fought came from the neighbouring villages, and that there are now many wounded suffering severely from their injuries. By showing a desire to be kind and a readiness to aid those who fought so gallantly in defence of their country, many of these unfortunate villagers have expressed a wish for the benefit of British surgical skill; in this they have been encouraged by Major Cavagnari, who has placed material at the disposal of Surgeon-Major Kelly of the Guides, under whom many are under treatment in a tent, near the Hospital of the Guides. Afghans, like Turks, as a rule, object to operative surgery as a means of relief, or of prolonging life; at the same time, some have been induced to submit to explorations for missiles and other operations. Lately, lateral lithotomy was performed on a young Afghan boy by Dr Kelly, assisted by Surgeon-Major Chesney of the 4th Ghorkas, and Surgeon-Major Porter of the Field Hospital. The operating-table, on this latter occasion, would have afforded considerable interest to many ingenious inventors of operation-tables and other surgical appliances. Devoid of all bolts, screws, levers, straps, and double inclines, it consisted of a pair of kajawars (square frameworks, covered with cord, for the conveyance of cooking utensils on camels), placed on a foundation of stones. Had the table been one of Weiss's best, the operation could not have been more successful. (British Medical fournal, 1879.) 